International Journal of Engineering \& Technology, $7(3.7)(2018)$ 179-181
International Journal of Engineering \& Technology
WPC
Website www.sciencepubco.com/index.php/IJET
Research paper

\title{
Temperature Compensation of Photovoltaic cell using Phase Change Materials
}

\author{
Tachakun Sarikarin $^{1 *}$, Amnart Suksri ${ }^{2}$, Tanakorn Wongwuttanasatian ${ }^{2}$ \\ IInsulation Technology and High Voltage Engineering Laboratory, Department of Electrical Engineering, Faculty of Engineering, \\ Khon Kaen University, 40002, Khon Kaen, Thailand \\ 2 Center for Alternative Energy Research and Development, Khon Kaen University, 40002, Khon Kaen, Thailand \\ *Corresponding authorE-mail: tachakun.pri@gmail.com; amnart@elec.kku.ac.th; tanwon@kku.ac.th
}

\begin{abstract}
The performance of photovoltaic module (PV) situated outdoors suffers from high temperature. When the high temperature of surrounding atmosphere is increased, the generation of electricity power drops rapidly. This paper is concerned with the temperature compensation technique of the cooling PV cell by using the phase change materials (PCMs). PCM used in this research is palm wax with the melting point at $52{ }^{\circ} \mathrm{C}$. We used a stainless steel container that is designed with three types of installation (fin type, groove type and tube type) to cover the surface area for heat exchanger purpose. The heat exchanger is installed at the back of PV cell. The test is conducted for all day (9AM-5PM) under the climatic condition of Khon Kaen, Thailand (latitude, $16^{\circ} 26^{\prime} 20^{\prime \prime} \mathrm{N}$ and longitude, 102 ${ }^{\circ} 49^{\prime} 43^{\prime \prime} \mathrm{E}$ ) during winter. It was found that the PV cell that is used PCMs installed container with fin type was able to produce more electric power to an order of 8.178 per cent than the controlled reference module.
\end{abstract}

Keywords: Photovoltaic cell, Phase change materials

\section{Introduction}

Today photovoltaic cell (PV cell) used for alternative energy because it is the best performance such as high power and reduce the pollution. The temperature of $\mathrm{PV}$ cell over $25^{\circ} \mathrm{C}$, The power drop of $0.65 \% /{ }^{\circ} \mathrm{K}[1]$.

The Researcher are divided type of cooling into 3 types; passive cooling (heat pipe based and fins), active cooling(spraying water and wind) and cooling by phase change material (PCMs) [2]. The passive cooling type used the copper water heat pipe can rejected heat with a total cell to an ambient temperature rise of only $40^{\circ} \mathrm{C}$ [3]. Active cooling type use the fan for reduce heat and it can increase the peak power up to $7.5 \%$ [4]. When water flow over PV Cell, it decreases temperatures up to $22^{\circ} \mathrm{C}$ [5]. The PCMs used the paraffin wax from natural for reduce heat from PV Cell under climatic condition [6]. The paraffin wax based RT42 was used within an in-house designed and fabricated PCMs containment was found an increase in relative electrical efficiency by $7.7 \%$ and an average reduction in module centre temperature by $3.8^{\circ} \mathrm{C}$ [7] but the paraffin wax are expensive and low melting point.

This research designed of PCMs container and used palm wax replacement the paraffin wax because the melting point higher than paraffin wax and reduce cost of PCMs.

\section{Materials and methods}

\subsection{Photovoltaic Cell}

Type of photovoltaic cell is poly-crystalline silicon with dimensions of 430x330x $25 \mathrm{~mm}$. The maximum power of PV cell is $20 \mathrm{~W}$. PV cell is installed on an easel. It is inclined with an angle of 15 degrees to the horizontal and facing south. The experiment compares reference module (without PCMs container) and test module (with PCMs container) in Figure 1 During experiment, measurement of voltage and surface temperature on PV cell were made. The voltage evaluation of the module was measured using digital multi-meter uni-t@ ut 106. The temperature evaluation of the module were recorded using a thermocouple type k model WR 22 in Figure 2 and data logging system was used to collect the temperature profile. The data were then recorded for 8 hours in a day (9AM-5PM) at an interval of 3 minutes.

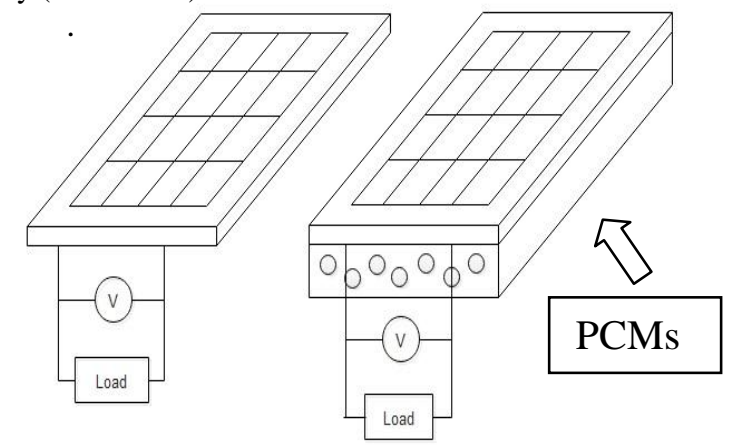

(a)

(b)

Figure 1: Measurement of voltage (a) reference module without PCMs container and (b) tested module with PCMs container. 


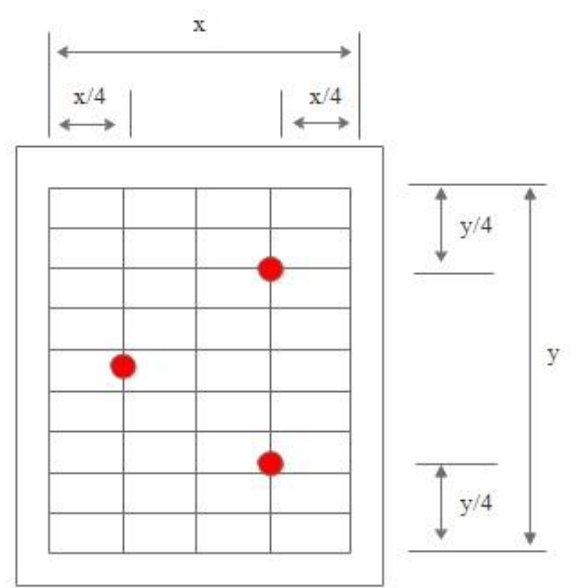

Figure 2: Measurement of temperature using thermocouple 3 point.

\subsection{PCMs Container}

PCMs container designed are 3 types namely; groove, tube, and fin are shown in Figure 3. The design of PCMs container is of mass equal. PCMs container was design to the increase the surface area for heat exchanger purpose. The PCMs container tube type was developed using $6 \mathrm{~mm}$ thick stainless steel with the dimension of $370 \times 310 \times 47$ $\mathrm{mm}$. It is buried with pipes using the dimension of $20 \mathrm{~mm}$ in diameter and 12 pieces with surface area of $2,667.48 \mathrm{~cm}^{2}$. The PCMs container groove type was developed by using $6 \mathrm{~mm}$ thick stainless steel with the dimension of $370 \times 310 \times 42 \mathrm{~mm}$. The size of the fin width is $30 \mathrm{~mm}$ with 8 rows and surface area of $4,158.8 \mathrm{~cm}^{2}$. The PCMs container fin type was developed by using $6 \mathrm{~mm}$ thick stainless steel with the dimension of $370 \times 310 \times 45 \mathrm{~mm}$. The size of the fin is $13 \mathrm{~mm}$ and 15 pieces with the surface area of $5,402 \mathrm{~cm}^{2}$. PCMs is used in this research is palm wax with melting point of $52{ }^{\circ} \mathrm{C}$.

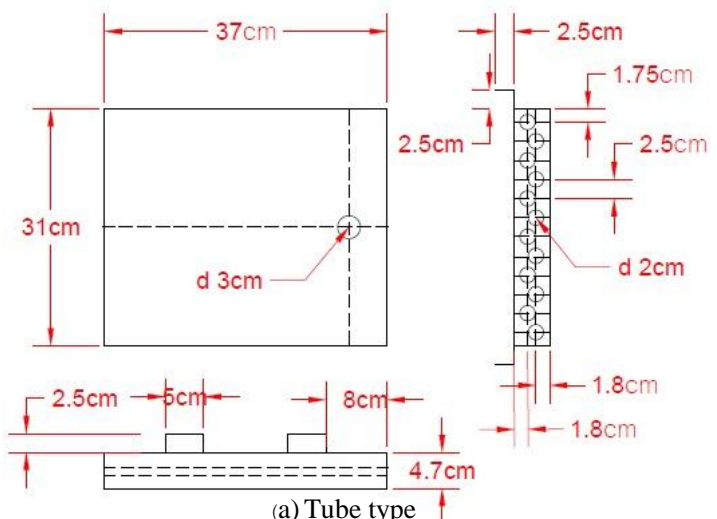

(a) Tube type 1

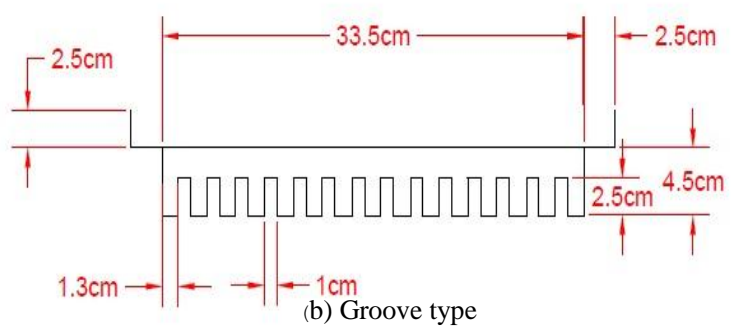

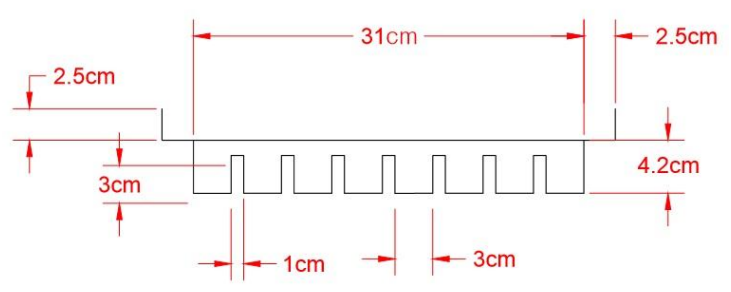

(c) Fin type

Figure 3: PCMs container (a) Tube type, (b) Groove type, (c) Fin type

\section{Results and Discussion}

\subsection{Temperature-Time}

Figure 4a shows a comparison between temperature and time of tube type. Palm wax absorbed temperature from the test module. Its maximum temperature of palm wax is $42.3{ }^{\circ} \mathrm{C}$. Figure $4 \mathrm{~b}$ shows the comparison between temperature and time of groove type. Palm wax absorbed temperature from the test module. Its maximum temperature of palm wax is $42.20{ }^{\circ} \mathrm{C}$. Figure $4 \mathrm{c}$ shows the comparison between temperature and time of fin type. Palm wax absorbed temperature from the test module. Its maximum temperature of palm wax is $45.90{ }^{\circ} \mathrm{C}$. The temperature of PV cell shown in table 2 .

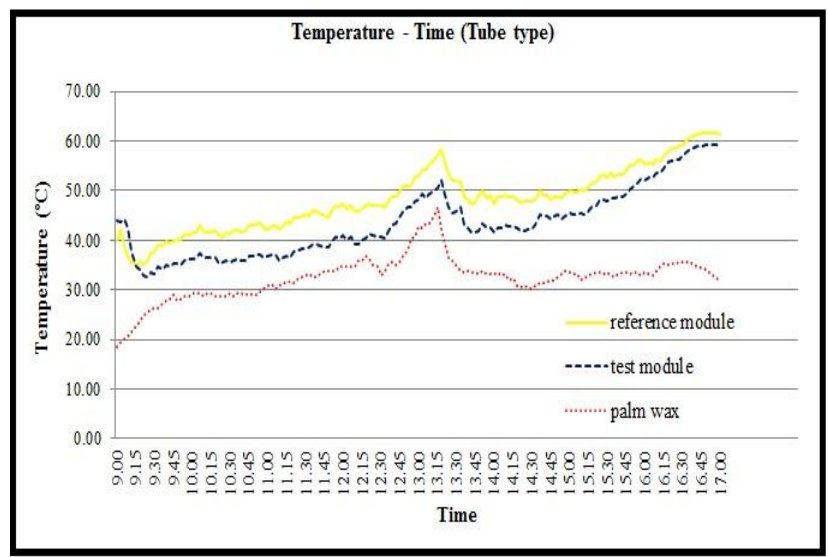

(a) Tube type

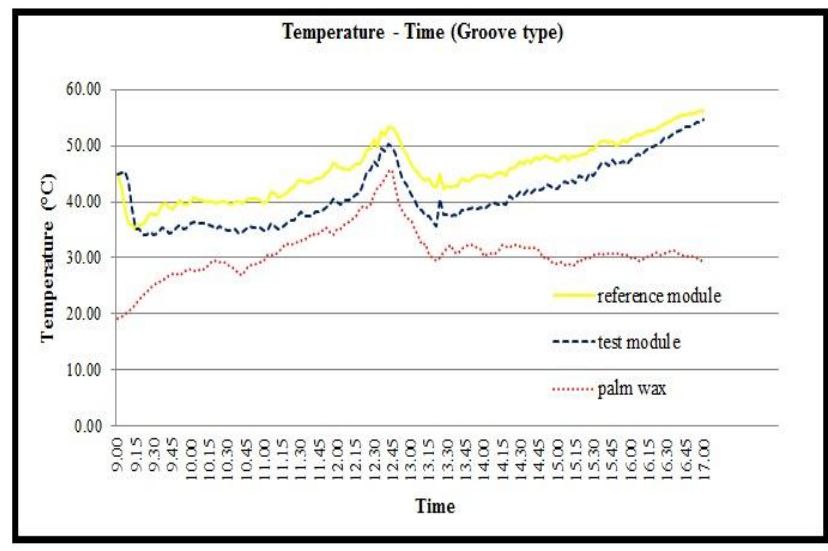

(b) Groove type 


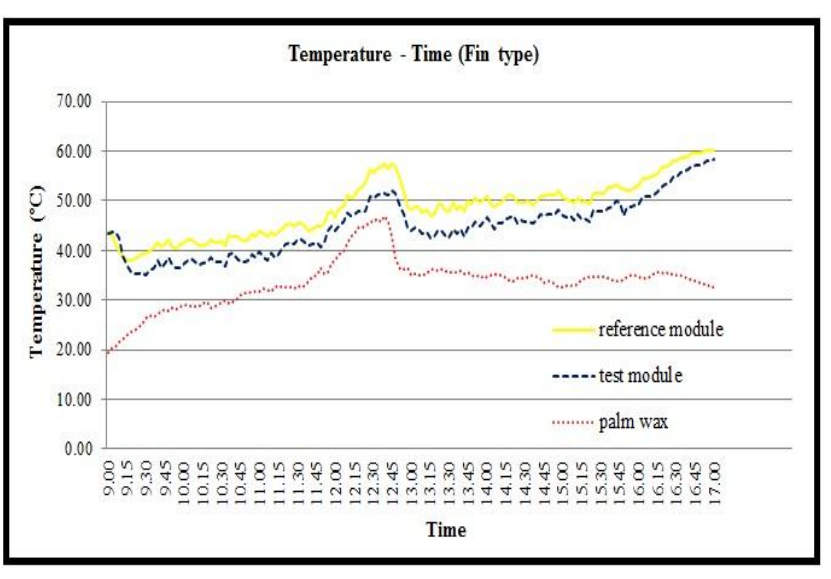

(c) Fin type

Figure 4: Comparison between temperature and time (a) type tube (b) type groove (c) type fin.

Table 1: Temperature of PV cell

\begin{tabular}{|c|c|c|c|c|}
\hline Type & $\begin{array}{c}\text { Electric pow- } \\
\text { er } \\
\text { (reference } \\
\text { module) } \\
(\mathbf{W})\end{array}$ & $\begin{array}{c}\text { Electric } \\
\text { power } \\
\text { (test mod- } \\
\text { ule) } \\
(\mathbf{W})\end{array}$ & $\begin{array}{c}\Delta \mathbf{P} \\
(\mathbf{W})\end{array}$ & $\boldsymbol{\%}$ \\
\hline tube & 6.716 & 6.962 & 0.246 & 3.657 \\
\hline groove & 9.744 & 10.310 & 0.566 & 5.813 \\
\hline fin & 4.260 & 4.608 & 0.348 & 8.178 \\
\hline
\end{tabular}

\subsection{Electric Power}

Figure 5 shows electric power of the experiment. Power increased of tube type is $3.657 \%$. Power increased of groove type is $5.831 \%$. Power increase of tube type is $8.187 \%$.The generation of electric power is shown in table 2

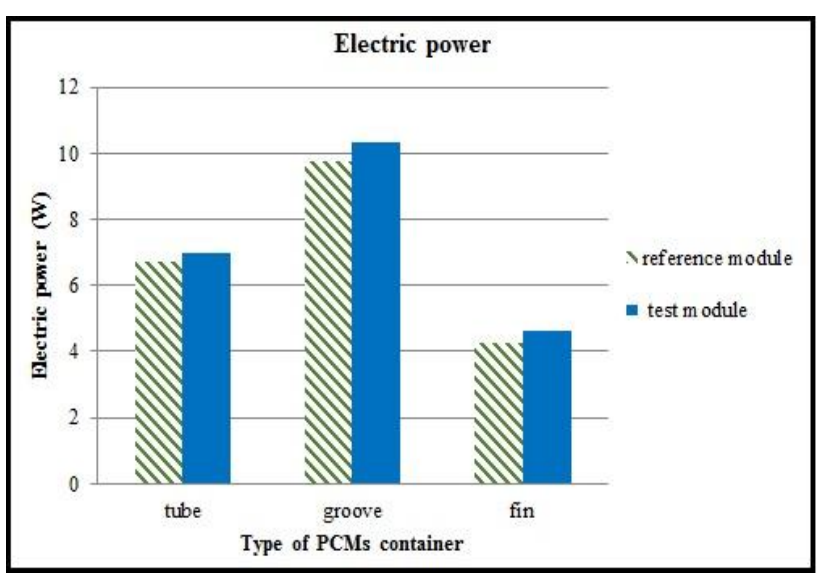

Figure 5: Show electric power

Table 2: Electric power produced

\begin{tabular}{|c|c|c|c|c|}
\hline Type & $\begin{array}{c}\text { Temperature } \\
\text { (reference } \\
\text { module) } \\
\left({ }^{\circ} \mathbf{C}\right)\end{array}$ & $\begin{array}{c}\text { Tempera- } \\
\text { ture } \\
\text { (test mod- } \\
\mathbf{u l e})\end{array}$ & $\begin{array}{c}\Delta \mathbf{T} \\
\left({ }^{\circ} \mathbf{C}\right)\end{array}$ & $\% \mathbf{T}$ \\
\hline tube & 53.277 & 48.640 & 4.637 & 8.703 \\
\hline groove & 48.443 & 44.373 & 4.070 & 8.402 \\
\hline fin & 52.343 & 47.107 & 5.237 & 10.004 \\
\hline
\end{tabular}

$60 \mathrm{~g} / \mathrm{cm}^{3}$ density

$70 \mathrm{~g} / \mathrm{cm}^{3}$ density

$80 \mathrm{~g} / \mathrm{cm}^{3}$ density

\section{Conclusion}

The design of PCMs container has a major contribution on decreasing temperature of $\mathrm{PV}$ cell. PCMs materials will operate with the melting point at $52{ }^{\circ} \mathrm{C}$. Heat conduction of PCMs starts at room temperature until a melting point. The best results of cooling PV were achieved by using PCMs container with fin type, second groove type and finally tube type. As for electricity generation, it was found that the PV cell that is used PCMs container fin type was able to produced more electric power than reference module to an order of $8.178 \%$

\section{Acknowledgement}

Authors would like to thank you to the Insulation Technology and High Voltage Engineering Laboratory, Department of Electrical Engineering, Khon Kaen University for supported this research. Also and Laboratory in Department of Chemical Engineering, Khon Kaen University for testing all of the specimens in this research, Lastly, Center for Alternative Energy Research and Development, Khon Kaen University.RUN : Research University Network Project ,Granted by RUN - Energy cluster, Thammasat University.

\section{References}

[1] E. Radziemska ., The effect of temperature on the power drop in crystalline silicon solar cells, Renewable Energ. 2003. 28: p. 1-12.

[2] S. Sargunanathan, A. Elango, and S. T. Mohideen., Performance enhancement of solar photovoltaic cells using effective cooling methods: A review, Renewable and Sustainable Energy Reviews. 2016. 64: p. 382-393.

[3] W. G. Anderson, P. M. Dussinger, D. B. Sarraf, and S. Tamanna., Heat pipe cooling of concentrating photovoltaic cells, Conference Record of the IEEE Photovoltaic Specialists Conference. 2008.

[4] A. S. Káiser and B. Zamora.,. Improving the Electrical Parameters of a Photovoltaic Panel by Means of an Induced or Forced Air Stream, Hindawi Publishing Corporation International Journal of Photoenergy. 2013

[5] S. Krauter., Increased electrical yield via water flow over the front of photovoltaic panels, Solar Energy Materials \& Solar Cells. 2004. 82: p. $131-137$.

[6] M. Edalatpour, A. Kianifar, K. Aryana, and G. N. Tiwari., Energy, exergy, and cost analyses of a double-glazed solar air heater using phase change material, Journal of Renewable and Sustainable Energy. 2016. 8(1): 015101.

[7] S. Sharma, A. Tahir, K. S. Reddy, and T. K. Mallick., Performance enhancement of a Building-Integrated Concentrating Photovoltaic system using phase change material, Solar Energy Materials \& Solar Cells. 2016.149: p. 29-39. 